\title{
The Ideal Concept of Presidential Threshold Arrangement to Achieve Constitutional Rights of New Political Parties in a Simultaneous General Election in Indonesia
}

\author{
Muhammad Mukhtarrija ; I gusti Ayu Ketut Rachmi Handayani; Agus Riwanto \\ Faculty of Law, University of Sebelas Maret, Indonesia \\ Email: mukhtarrija@gmailcom \\ http://dx.doi.org/10.18415/ijmmu.v5i3.244
}

\begin{abstract}
This study raises the legal issue against the enactment of Law No. 7 of 2017 on General Elections in Indonesia. The law has violated the constitutional rights of new political parties of the simultaneous general election participants that began in 2017. The injustice is seen in article 222 which requires the provision of presidential threshold for political parties nominating the president and vice-presidential pairs based on the results of general elections in 2014. If this provision is applied, automatically the new political parties of the simultaneous general election participants in Indonesia do not have the opportunity to nominate a couple of presidents and vice presidents. Based on the Constitution of the 1945 Constitution, the president and vice president are nominated by a political party or a coalition of political parties participating in the general election. Considering the constitution applicable in Indonesia should every political party participating in the general election have equal rights and opportunity in carrying the candidate of president and vice president to be elected by the people in a democracy.
\end{abstract}

Keywords: Constitution; General election; Indonesia; Injustice; Presidential threshold

\section{Introduction}

The minimalist democratic theory explained by Joseph Shumpeter that elections are an arena that accommodates the competition between political actors who gain the power of people's political participation to make choices and liberalize civil and political rights of citizens (Janpatar Simamora., 2016, p. 2). The concept of democracy that power comes from the people is exercised by and for the people. Departing from the idea then it can be said that electing and elected in the general election is a deviation from the sovereignty of the people who subsequently serve as a fragment of the rights of every citizen (Nur Hidayat Sardini., 2011, p. 1). Democracy is a means for citizens to participate in electing legitimate governments by constitution.

Elections are a manifestation of procedural democracy, although democracy is not the same as elections, but elections are one of the most important democratic foundations that must also be democratically organized. typically in countries calling themselves democracies of draft General 
Elections to elect public officials in the legislative and executive branches at both the central and regional levels (A. Mukthie Fadjar., 2009, p. 11).

According to Andrew Reynolds in Efriza said that the election is a method in which the votes obtained in the election translate into seats won in parlmen by parties and candidates. Elections are an important means of choosing representatives of the people who will actually work on behalf of the process of state policy (Efriza., 2012, p. 360). Elected representatives of the people, have legitimate legitimacy to work and make policy in the government of a country.

Elections are a means of selecting and filling political positions in government as representatives of the people held democratically and fairly by having equal opportunity for any particular group, party or group without discrimination and carried out regularly and periodically organized according to the state constitution. Given the importance of elections in a democratic country, it is necessary to be specifically regulated in the country's constitution.

General Election in Indonesia based on Constiutution of Amendment to The 1945 Constitution Article 22 E reads: "General elections shall be held in a direct, public, free, secret, honest and fair every five years". he regulation of the general election in the 1945 Constitution proves the importance of the conduct of the General Elections in Indonesia as an embodiment of the democratic system. Elections in Indonesia aims to elect their representatives to sit in the structure of the executive and legislative governments.

General elections as a manifestation of a democratic system that has recently received responses from various countries as an ideal means or mechanism in the process of peaceful and orderly transition of power. Implementation of peaceful elections and terib, then the process of transition of power in a country will be able to walk well. The practice of the electoral system implemented in Indonesia recently, the fact has noted that the model of direct elections has brought about a number of positive impacts. One of them is the birth of the nation's leaders, both the President and a number of regional heads based on the majority of Indonesians (Janpatar Simamora., 2016, p. 2).

The Constitutional Court of the Republic of Indonesia has issued Decision of the Constitutional Court Number 14/ PUU-XI/ 2013 concerning the implementation of the simultaneous General Elections to be held in the 2019 general election and the subsequent general elections. The simultaneous general elections of the legislative elections of the presidential and vice presidential elections are held simultaneously. The necessity of simultaneous general election is the result of judicial review (judial riview) of Law Number 42 Year 2008 regarding Presidential Election to the 1945 Constitution to the Constitutional Court of the Republic of Indonesia (Sodikin., 2014, p. 20).

The concept of a simultaneous general election is a political policy to merge the implementation of the legislative elections and the executive general election in one day of voting (Ria Casmi Arrsa., 2014 p. 532). Concurrent elections are simultaneous elections of both the legislative and executive elections.

As the legal basis for the simultaneous general elections in Indonesia, the House of Representatives of the Republic of Indonesia (DPR RI) ratified Law Number 7 Year 2017 on general election based on the decision of the Constitutional Court. The implementation of 2019 general election shall be conducted simultaneously based on Law Number 7 Year 2017 article 167 point 1 which reads: "Elections are held every 5 (five) years. " The holding of the General Elections every 5 (five) years to elect President and vice presidents, the House of Representatives of the Republic of Indonesia (DPR RI), the Regional Representative Council of the Republic of Indonesia (DPD RI), Provincial House of Representatives Provincial and Regency (Provincial and Regency DPRD). 
The enactment of Law No. 17 of 2017 on General Elections raises new legal issues against the implementation of the electoral system in Indonesia. Law Number 7 Year 2017 on General Election still maintains the provision of presidential threshold under Article 222 which reads: "The Candidate Pair is nominated by a Political Party or a Joint Political Parties of the Electoral Participant who fulfill the seat requirement requirement of at least $20 \%$ (twenty percent) of the total seats of the People's Legislative Assembly or obtain 25\% (twenty-five percent) of the nationally valid votes in Member Elections House of Representatives before".

According to Harun Husein et.al., said that the definition of the presidential threshold is the regulation of the level of support threshold from the House of Representatives, either in the form of ballot amount or the number of seats that must be obtained by the participating political parties elections in order to nominate the President of the political party or by a coalition of political parties (Sigit Pamungkas., 2009, p.19). The definition of the presidential threshold is an arrangement for the political parties participating in the general election to be able to propose the pair of presidential and vice presidential candidates based on the national legitimate ballot system or the number of seats in the Legislature. Elected political parties eligible to meet presidential threshold thresholds under the provisions of election law may enter into coalitions with other electoral contesting political parties.

The provisions of this Presidential threshold are discriminatory against the new political parties of the 2019 general election participants. The new political political party does not have any number of seats or votes based on the previous elections of 2014. In connection with Article 222 of Law Number 7 Year 2017 concerning the Election is in contravention of the Constitution in Indonesia. This journal gives the Ideal Concept of Presidential Threshold Arrangement to Achieve Constitutional Rights of New Political Parties in a simultaneous general election.

\section{Methodology}

According to Peter Mahmud Marzuki, legal research is an activity know-how in the science of law, not just know-about. As an activity know-how, legal research is conducted to solve the legal issues faced (Peter Mahmud Marzuki., 2014, p. 60) based on the opinion of Peter Mahmud Marzuki that there is no need for the term normative legal research, because legal research or Dutch rechtsonderzoek is always normative. Similarly, the normative juridical term is not known in legal research. With such a statement it is clear that the study is normative. It's just that the approach and the legal materials used should be put forward (Peter Mahmud Marzuki., 2014, p. 55-56).

The object of legal science is the coherence between legal norms and legal principles, between the rule of law and legal norms, as well as the co-operation between behavior (act)-not individual behavior with legal norms. Thus it can be said that the point of factoring in the study of law is to understand the intrinsic conditions of the rule of law (Peter Mahmud Marzuki., 2014, p. 41-42).

\section{The Ideal Concept of Presidential Threshold Arrangement to Achieve Constitutional Rights of New Political Parties in a Simultaneous General Election in Indonesia}

This term is derived from the Greek word demokratia (people's power), formed from the word demos (people) and kratos (power), referring to the political system that emerged in the mid-5th and 4th century BC in Ancient Greece (Azumardi Azra., 2005, p. 125). Democracy is concerned with the will, opinions and views of the people, the style of democratic government is chosen through agreement by way of consensus. So that strong democracy is a democracy that comes from people's conscience to 
achieve justice and prosperity of the people (Zakaria Bangun., 2008, p. 2). The people have an active participation in determining the direction and policy of government.

The people have a strategic role in determining the people's representatives who hold the power of government through the participation of the general election. Participation in elections and presidential elections by choosing parties or candidates is one form of political participation (A.B. Barrul Fuad., p. 480). The process of people's participation through democratic parties is conducted in a real and responsible manner without any pressure from any party.

Elections are a part of democracy within a country that must be implemented on the basis of constitution. The Constitution is the basic law that is used as the guidance in the administration of a country. The Constitution may be a basic written law commonly referred to as the Constitution, and may not be written. Not all countries have a written constitution or the Constitution (Jimly Asshiddiqie., 2006, p. 35). The written Constitution becomes the supreme law in a country where statutory legislation should not be contrary to the constitution.

The preparation of a written constitution derives from the values and basic norms that live in society in practice state organizers also influence the formulation of a norm into the text of the Constitution (Jimly Asshiddiqie., 2006, p. 36). Formulation of the constitution in writing comes from a living norm in the society that characterizes the country.

Constitution is the highest order in national law (Hans Kalsen., 1995, p. 126). The Constitution is the standard in making the legislation under it based on the concept of hierarchy of legislation. Legislation that is not in accordance with the constitution by law should be revoked. The drafting of the constitution in a country is not discriminatory to any person or group. General elections constituting part of the constitution in Indonesia should be carried out fairly for each group. The simultaneous general electoral system under article 222 of Law No. 7 of 2017 is very much against the prevailing constitution in Indonesia.

According Sigit Pamungkas in Efriza said that the electoral system as a set of motodes or rules to transfer voting votes into a representative institution (Efriza., 2012, p. 360). According to Giovanni Sartori in Efriza said that the electoral system as a part of the most central part of the work of the political system. The political system is not only a political instrument that is easily manipulated, it also forms a party system and influences the spectrum of representation. In addition, the electoral system is a means of the people (Efriz., 2012, p. 360).

According to Ben Reilly and Andrew Reynolds in Efriza said that the electoral system is designed to fulfill three things, in which they are an integral whole. The three things mentioned are (Efriza., 2012, p. 360):

1. To translate the number of votes obtained in the general election to the seats of the legislature

2. The electoral system acts as a liaison vehicle that enables people to collect responsibility or promises of representatives they have chosen

3. Providing incentives to those fighting over power to draft calls to voters in different ways

Electoral system is a method as a reference about the governance of elections. The electoral system is clearly stated in the rules of legislation applicable to the concept of legitimate elections. In formulating the method of elections in a country should be fair and not discriminate against a particular group. 
This justice is the equality among members of society in a joint action. The equation is a point located between "more" and "less" (intermediate). So justice is a point or a relative equation (arithmetical justice) (Euis Amalia., 2009, p. 117). Implementation of the concept of justice undertaken by the state should pay attention to equal opportunities and the absence of differences to certain people, groups and groups.

Equal principle of justice is when applied political procedures established by the constitution will have the principle (equality) participation. This principle states that all citizens have equal rights to take part, and to determine the outcome of the constitutional process (John Rawl., 2011, p. 280). The principle of justice in the constitution is that every citizen or group has political equality to take part in the process of determining the direction and purpose of the state without any discrimination.

There are two principles of justice according to John Rawls namely (John Rawl., 2011, p. 72):

1. Everyone has equal rights over a broad basic freedom

2. Social and economic inequality is set in such a way that it can benefit everyone and all open positions and positions of everyone

The principle of justice of justice according to Joh Rawls means that any individual, group or group having the same status of a country should be treated. Policies made by the state should be ensured equality, equal opportunity to be able to compete in accordance with existing rules.

The principle of participation also states that all citizens have equal access, at least the formal meaning of public affairs. Any qualified person can join a political party, pursue the elected positions and hold the reins of power (John Rawl., 2011, p. 283). Through open access to public participation the public is a guarantee of political rights that must be protected by the constitution. Legislation that limits the political rights of the people should be revoked or revamped.

Equality for everyone, especially if judging from fair equality of opportunity or equal opportunity principle. The Constitutional Court of the Republic of Indonesia provides the substance of justice by giving the same opportunity when the inequality principle takes place. Rawls's principle of justice also strictly emphasizes that the equal opportunity principle should be prioritized from the differences principle when it occurs under conditions of opportunity inequality (Dian Agung Wicaksono., 2011, p. 102-103). Implementation of the simultaneous general elections in Indonesia should apply the principle of justice for all political parties to run a couple of candidates for president and vice president.

The enactment of Article 222 of Law Number 7 Year 2017 regarding General Election in Indonesia is considered to have violated the constitutional rights of new political parties in the general election. New political parties automatically do not have the constitutional right to nominate several presidents and vice presidents.

Whereas according to the Constitution amendments to the 1945 Constitution says that political parties participating in the election are entitled to nominate a couple of presidents and vice presidents. This provision is based on Article 6B Number 2 of the article: "A couple of candidates for President and Vice President shall be nominated by a political party or a coalition of political parties participating in the general election prior to the election". So by law the application of Article 222 of Law Number 7 Year 2017 on General Elections contradicts the Constitution as the highest law in the state. 
Theoretically, the concept of electoral srentak applies to countries that embrace presidential systems. In contrast to the parliamentary oversight system, where legislative elections will automatically produce executive officers. For political parties or coalitions of political parties winning the general election control the majority of parliamentary seats so as to form a government (Muhadam Labolo \& Teguh Ilham., 2017, p. 248).

The essence of the concept of simultaneous general elections is to combine the implementation of the legislative elections and the executive election in one day of election. The goal is to create a congruent electoral government. It means. The election of executive officers who have legislative support so that the government is stable and effective (Muhadam Labolo and Teguh Ilham., 2017, p. 248).

Countries that embrace the system of parliamentary government no longer need to conduct general elections simultaneously because at the time of the legislative elections then it means voters have chosen as well as officials ekskutif. This is because a political party winning a general election or holding a majority of seats in the legislature has the right to show the prime minister and the executive officer below him (Muhadam Labolo and Teguh Ilham., 2017, p. 248).

According to Mark Pyane et al in Muhadam Labolo and Teguh Ilham stated that stability and effectiveness yag became the basis of the implementation of simultaneous general elections (Muhadam Labolo and Teguh Ilham., 2017, p. 252). Concurrent general elections that have stability and effectiveness will be created if the electoral process meets justice for each party through the rules of electoral law.

Ramlan Surbakti in Muhadam Labolo and Teguh Ilham also mentioned the process of organizing high quality public memoirs among others (Muhadam Labolo and Teguh Ilham., 2017, p. 253):

a. Elections are organized on the basis of principles of democratic elections

b. The high degree of voter participation, the low number of unauthorized votes, and the integrity of election results (the results of general elections established by the General Election Commission in accordance with actual voter vote)

c. Elections are organized efficiently

The purpose of a simultaneous general election is to create a government that is formed from the results of a simultaneous general election that is completely stable and effective. The simultaneous model of electoral execution is a general election that really leads to that goal (Muhadam Labolo and Teguh Ilham., 2017, p. 255). The implementation of Law Number 7 Year 2017 on General Election has not fulfilled the stability and effectiveness of the implementation of simultaneous general elections. This is due to the unfairness of equality of simultaneous general elections between political parties participating in new elections and political parties that have seats in the House of Representatives before the result of the previous General Election.

Ideal concept that must be done in realizing a common system of simultaneous general pemiihan which has stability and effectiveness is back to the constitution Amendment UUD 1945. Applying the regulation of presidential threshold threshold based on Article 222 Law Number 7 Year 2017 about General Election is a form of constitutional violation in Article 6 Number 2 of the 1945 Constitution.

Every political party participating in a general election constitutionally has the same right to nominate a vice presidential vice-president. The enactment of Article 222 of Law No. 7 of 2017 on General Elections of the form of kempetisi seizes power unfairly. So the process of elections in Indonesia 
conducted simultaneously should give priority to the opportunity for all political parties participating in the general election.

To strengthen the presidential system in Indonesia, the ideal need to use a strict political party selection method for politics to minimize many political parties participating in the general election. the selection of political parties is stronger, more constitutional than eliminating the election candidates' new party opportunity to nominate the presidential and vice-presidential pairs. Political parties will organize structural improvements so they can qualify as simultaneous election participants and can nominate a presidential couple with no vice president.

\section{Conclusion}

Elections are part of a legitimate succession of government leadership according to the constitution in Indonesia. Elections must be conducted fairly for each particular group or political party. The enactment of Law Number 7 Year 2017 on General Election in Indonesia has violated the Constitution Amendment to the 1945 Constitution as the highest Law.

The violation of the constitution is seen in the neglect of the political rights of new parties of simultaneous general election participants to nominate the presidential and vice-presidential pairs. Whereas the political right of each party participating in the general election is having the opportunity to nominate a couple of presidents and vice presidents as contained in Article 6A Number 2 which reads "A couple of candidates for President and Vice President shall be nominated by a political party or a coalition of political parties participating in the general election before the election". The political rights of the new party shall be regarded as the same as the political party which already has a vote based on the result of the previous general election.

\section{Acknowledgement}

The author would like to thank the Faculty of Law of Sebelas Maret University Surakarta in Indonesia as the place where the writer learns. Thank You to the Lecturers of Law Faculty of Sebelas Maret University in Indonesia who guided the authors in compiling this journal.

\section{References}

A B Barrul Fuad. Political Identity and Election in Indonesian Democracy: A Case Study in Karang Pandan Village-Malang, Indonesia. (Procedia Environmental Sciences volume 20).

A Mukthie Fadjar. (2009). Democratic and Qualified General Election: Legal Settlement of General Election Violations and PHPU. Journal Konstitusi, 6(1): 1-24.

Azumardi Azra. (2005). Democracy, Human Rights, and Civil Society. Jakarta: Prenada Media.

Dian Agung Wicaksono.(2011). The Role of the Constitutional Court of the Republic of Indonesia in Achieving Fair Equality Of Opportunity In Indonesia (Analysis of Decision No. 117/ Puu-Vii/ 2009). Journal Konstitusi 9(1): 84-112.

Efriza. (2012). Political Explore: A Study of Political Science. Bandung: Alfabeta. 
Euis Amalia. (2009). Distributive Justice in Islamic Economics. Jakarta: Grafindo Persada.

Hans Kalsen. (1995). Pure Law Theory: The Basics of Normative Law Science as an Empirical Law Science, by Somardi.Jakarta: Rimdi Press.

Janpatar Simamora. (2014). Welcoming the Regime of Elections Concurrently. Journal Rechsvinding 3(1): 1-18.

Jimly Asshiddiqie. (2006). Constitution and Indonesian Constitutionalism. Jakarta: Konstitusi Press.

John Rawl. (2011). Theory of Justice: the Basics of Political Philosophy to Achieve Social Welfare in the State.Yoygakarta: Pustaka Pelajar.

Muhadam Labolo and Teguh Ilham. (2017). Political Parties And Electoral Systems in Indonesia. Jakarta: Rajagrafindo.

Nur Hidayati Sardini. (2011). Restoration of General Election in Indonesia.Jakarta: fajar Media Press.

Peter Mahmud Marzuki. (2014). Legal Research.Jakarta: Prenadamedia Group.

Ria Casmi Arrsa. (2014). Political Explore: A Study of Political Science. Journal Konstitusi, 11(3): 515537.

Sigit Pamungkas. (2009). Subject Election.Yogyakarta: Laboratorium Jurusan Ilmu Pemerintahan dan Jurusan Ilmu Pemerintahan Fisipol UGM.

\section{Copyrights}

Copyright for this article is retained by the author(s), with first publication rights granted to the journal.

This is an open-access article distributed under the terms and conditions of the Creative Commons Attribution license (http://creativecommons.org/licenses/by/4.0/). 